\title{
INTERPRETASI AWAL TEMUAN GIGI MANUSIA DI SITUS BALA METTI, BONE DAN SITUS LEANG JARIE, MAROS, SULAWESI SELATAN
}

\author{
The Early Interpretation of the human teeth at Bala Metti Sites, \\ Bone and Leang Jarie Sites, Maros, South Sulawesi
}

\author{
Budianto Hakim \\ Balai Arkeologi Sulawesi Selatan \\ Jl. Pajjaiyang No. 13 Sudiang Raya Makassar, Indonesia \\ budiantohakim@yahoo.co.id
}

Naskah diterima: 16/02/2017; direvisi: 10/05-07/06/2017; disetujui: 09/06/2017

Publikasi ejurnal: 29/06/2017

\begin{abstract}
The results of archaeological studies during this period, both from the colonial era until now, there has been no report on human skeletal findings from cultural supporters of the plestosen period in South Sulawesi. Existing reports, only limited to the findings of human remains of holosen period Mongoloid characterized. Therefore, in this paper will be perensented some new data of research results to be able to give a preliminary interpretation of who human supporters of stone culture in South Sulawesi. Human teeth found in the excavation asosiated with stone tools, in particular the jagged arrowhead and mikrolit on the website of Bala Metti. If the tooth is from ras Mongoloid then it can be said that jagged arrowhead has also produced during the farm. The analysis method applied in this writing is method of excavation and comparation.
\end{abstract}

Keyword: Interpretation, Human Teeth, and Sites

\begin{abstract}
Abstrak
Hasil-hasil penelitian arkeologi selama ini, baik dari sejak zaman penjajahan hingga sekarang belum ada laporan tentang temuan rangka manusia dari pendukung budaya masa plestosen di Sulawesi Selatan. Laporan yang ada, hanya terbatas pada temuan sisa-sisa manusia masa holosen yang berciri Mongoloid. Oleh sebab itu, dalam tulisan ini akan disajikan beberapa data baru hasil penelitian untuk dapat memberi interpretasi awal tentang siapa manusia pendukung dari budaya batu di Sulawesi. Gigi manusia yang ditemukan dalam penggalian berasosiasi dengan alat-alat batu, khususnya mata panah bergerigi dan mikrolit di situs Bala Metti. Jika gigi manusia tersebut adalah dari ras Mongoloid, maka dapat dikatakan bahwa mata panah bergerigi juga telah diproduksi pada masa bercocok tanam. Metode analisis yang diterapkan dalam penulisan ini adalah metode ekskavasi dan metode komparasi atau perbandingan.
\end{abstract}

Kata Kunci: Interpretasi, gigi manusia dan situs

\section{PENDAHULUAN}

Sejak berakhirnya zaman Es atau awal holosen penghunian manusia di Nusantara memperlihatkan perkembangan yang cukup signifikan, seperti terlihat pada penemuan sisa manusia yang menempati sebaran geografis yang lebih luas diberbagai bagian Nusantara. Manusia yang hidup pada kala tersebut merupakan evolusi dari manusia modern awal, walaupun tidak menutup kemungkinan adanya proses migrasi baru yang memasuki Indonesia setelah akhir Zaman Es. Untuk membedakannya dari manusia modern awal, manusia yang hidup pada periode ini dinamakan "Manusia modern yang lebih kemudian" (Zaim dkk, 2012:191).

Data mengenai sisa-sisa manusia pada periode ini sebagian besar ditemukan dari situs-situs gua hunian prasejarah, dengan perkecualian dari situs-situs terbuka bukit kerang yang wilayah persebarannya terbatas di sepanjang pesisir timur Sumatera Utara-Aceh. Dari penemuan tersebut dapat diketahui manusia modern ini secara fisik mencirikan ras Australomelanesid. 
Wilayah sebaran penemuan sisa manusia dari pertanggalan paruh pertama Holosen, meliputi situs Bukit Kerang, Binjai Tamiang, Sumatera yang diteliti oleh van Stein Callenfels, 1920-an. Ciri manusia yang ditemukan di daerah ini adalah berciri Papua-Melanesid. Di Jawa antara lain ditemukan di Gua Lawa, Sampung, Gua Sodong, Puger, Gua Marjan, Gua Petpuruh, Song Keplek, Jawa Timur dan Gua Broholo, Gunung Kidul, DI Yogjakarta. Di Kalimantan ditemukan di Gua Babi, Pegunungan Meratus dan Gua Tengkorak, Kalimantan Selatan; Di Sulawesi ditemukan di Gua Ululeba, Bone, Gua Karrasa, Maros, Leang Codong, Soppeng, Sulawesi Selatan; Di Flores ditemukan di Leang Toge, Liang Momer dan Liang Panas (Zaim dkk, 2012:191-205).

Penjelasan representatif tentang prasejarah nusantara baik manusia maupun budayanya di kala Holosen sangat terbatas dan secara umum masih bersifat hipotetik. Kenyataan ini merupakan suatu tantangan, mengingat kala Holosen merupakan rentang waktu yang sangat penting artinya dalam sejarah peradaban. Temuan sisa-sisa manusia dari beberapa situs di atas, telah menegaskan bahwa transmisi genetik manusia nusantara sekarang sudah jelas berasal dari masa Holosen awal dan tentu saja, pola-pola etnografi sekarang juga berakar dari masa tersebut. Untuk selanjutnya, budaya awal kala Holosen tersebut memiliki ciri pola ekonomi berburu dan mengumpul makanan tetapi sudah mengalami kemajuan (Duli dan Nur, 2016: 34).

Hasil-hasil penelitian arkeologi, baik dari sejak zaman penjajahan hingga sekarang belum ada laporan tentang temuan rangka manusia dari pendukung budaya masa plestosen di Sulawesi Selatan. Laporan yang ada, hanya terbatas pada temuan sisasisa manusia masa holosen yang berciri Mongoloid. Lokasi penemuan sisa-sisa manusia, antara lain ditemukan pada situs Gua Codong, Soppeng, Gua Ululeba dan
Leang Tumatua Kacicang di kawasan Bonto Cani, Bone dan Gua Bola Batu, dekat Barebbo, Bone serta beberapa temuan gigi manusia di Leang Karrasa, Maros. Peneliti yang pernah mencoba mencari sisa-sisa manusia pada beberapa gua di Sulawesi Selatan, antara lain; Sarasin bersaudara, van Stein Callenfels. H.D. Noone, A.A. Cense tahun 1933. Informasi temuan sisa-sisa mansia baru diperoleh, ketika van Heekeren mengadakan penelitian antara tahun 19371950an (Poesponegoro dkk, 1984).

Permasalahan di atas, sampai sekarang belum terjawab. Namun untuk sementara, ada penjelasan logis yang dapat dikemukan bahwa tidak ditemukannya sisa manusia dari masa Plestosen di Sulawesi Selatan, sebab kemungkinan pertama titik penggalian yang selama dipilih oleh peneliti belum tepat; kedua kemungkinan penanganan mayat bagi ras Austromelanised di Sulawesi Selatan berbeda dengan tempat lain di Indonesia (dibakar atau digantung dipohon); ketiga, kemungkinan dalam penggalian arkeologi selama ini, sebenarnya ada sisa manusia. Namun data itu terlewatkan, karena dalam penggalian arkeologi di Sulawesi tidak dilibatkan ahli antropologi ragawi (Zaim dkk, 2012:205).

\section{METODE PENELITIAN}

Tipe penelitian adalah eksplanatif atau deskriptif, yaitu dengan memberikan gambaran data arkeologi yang ditemukan, baik dalam kerangka waktu, bentuk, maupun keruangan serta mengungkapkan hubungan di antara berbagai variabel penelitian. Data arkeologi yang dimaksudkan meliputi artefak, ekofak, dan fitur (arti sempit) serta konteks (matriks, keletakan, asosiasi, stratigrafi) dan sebaran dalam satu situs (arti luas).

Metode pengumpulan data dipilih dengan melakukan survei dan ekskavasi. Ekskavasi merupakan salah satu teknik pengumpulan data melalui penggalian tanah yang dilakukan secara sistematis untuk menemukan suatu atau himpunan tinggalan 
arkeologi dalam situasi in situ. Ekskavasi kali ini termasuk dalam ekskavasi penelitian (research excavation), yaitu ekskavasi untuk melakukan penelitian mendalam. Dilihat dari liputannya (coverage), ekskavasi ini merupakan ekskavasi pilihan (selective excavation) dengan memilih tempat tempat tertentu di suatu situs, untuk memperoleh data semaksimal mungkin dengan waktu pelaksanaan yang terbatas.

Sementara metode survei yang dilakukan adalah acak terhadap kawasan karst yang diperkirakan memiliki potensi adanya ceruk atau gua. Selain itu, survei juga dilakukan terhadap kawasan karst di Desa Pattuku dan Desa Langi berdasarkan informasi penduduk tentang keberadaan sebuah gua atau ceruk. Pengamatan terhadap seluruh gua atau ceruk yang ditemukan dalam survei, selanjutnya diamati seluruh permukaan dan lingkungan sekitarnya.
Tujuannya untuk mengetahui potensi arkeologi setiap gua yang diamati. Hasil pengamatan dalam survei tersebut, selanjutnya merokomendasi ceruk atau gua yang berpotensi untuk diteliti lebih lanjut (ekskavasi).

\section{HASIL DAN PEMBAHASAN}

\section{Situs Balang Metti}

Situs Gua Bala Metti dan beberapa gua yang telah disurvei terletak di desa Pattuku, Kecamatan Bontocani, Kabupaten Bone. Sebagian wilayah Desa Pattuku adalah areal perkebunan dan persawahan masyarakat yang berada disekitar gugusan pegunungan gamping. Khusus di Desa Pattuku antara satu dusun dengan dusun lainnya sedikit lebih dekat sehingga sedikit lebih ramai. Secara astronomi situs Gua Bala Metti terletak pada $05^{\circ} 03^{\prime} 35$. 0" LS dan $119^{\circ}$ 57' 54.1" BT dan situs-situs

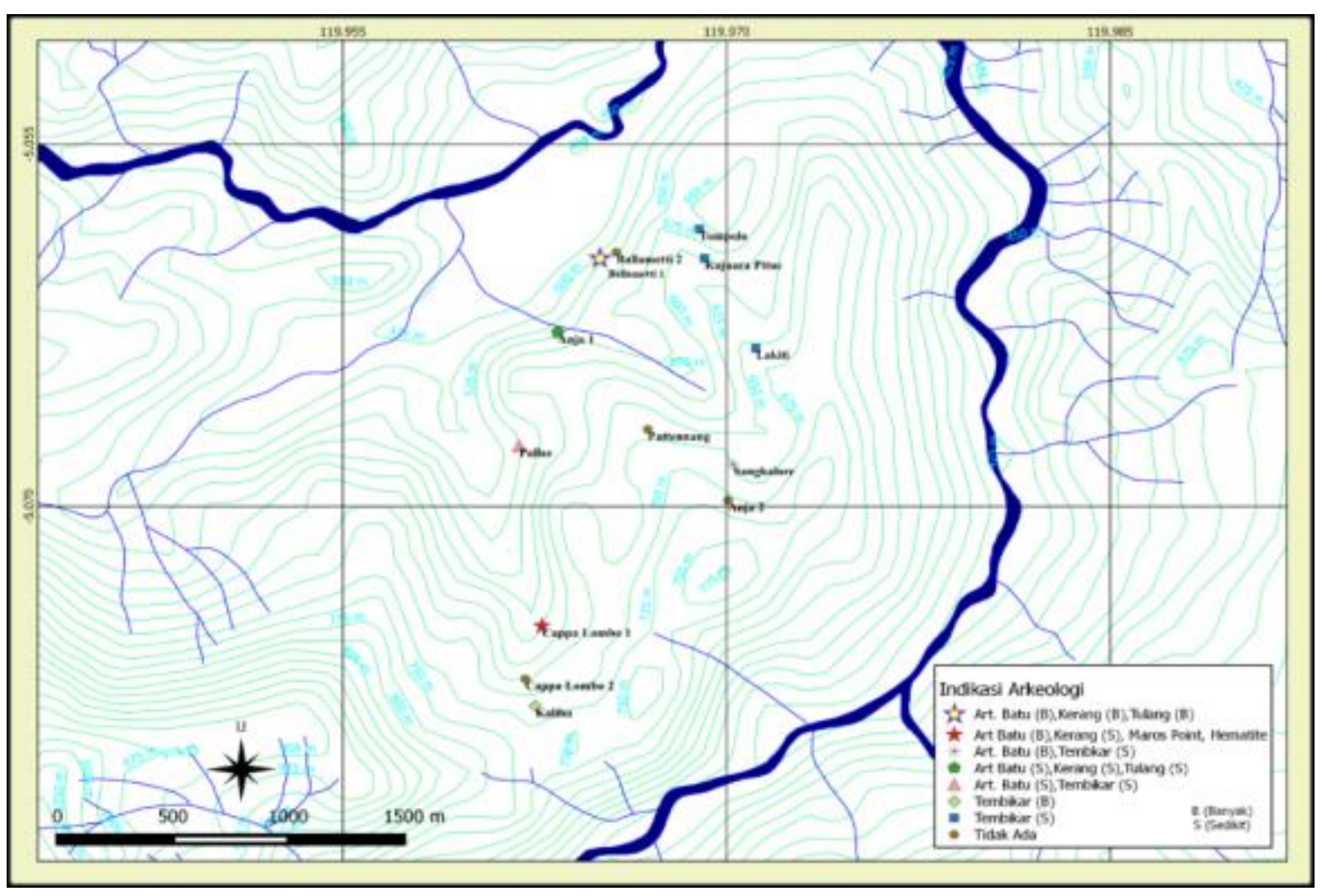

Gambar 1. Peta sebaran indikasi arkeologi di Situs Bala Metti, Kecamatan Bontocani, Kabupaten Bone

(Sumber: Dokumentasi Balar Sulsel, Tahun 2014). 


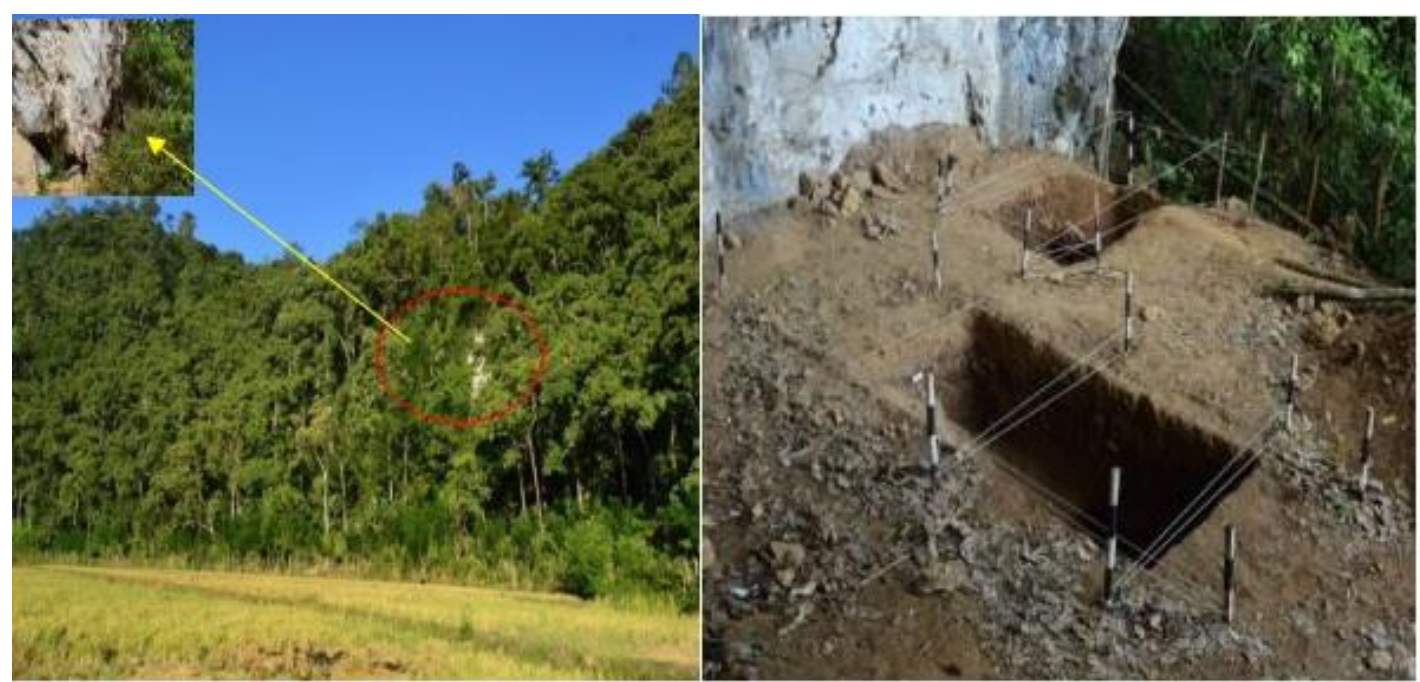

Gambar 2. Keletakan situs dan Kotak Ekskavasi di Situs Bala Metti, Kec. Bontocani, Kabupaten Bone.

(Sumber: Dokumentasi Balar Sulsel, Tahun 2016)

lainnya di Desa Pattuku keletakannya dapat dilihat pada peta situs di bawa (Balar Sulsel, 2014).

Keletakan gua kurang lebih $1 \mathrm{~km}$ dari pusat Desa Pattuku atau posisinya ditepi jalan poros desa antara Desa Pattuku dan Desa Langi. Ketinggian gua \pm 511 meter di atas permukaan laut atau memilki ketinggian \pm 20 meter dari permukaan tanah yang sejajar dengan kaki bukit kapur dimana gua tersebut berada. Situs ini merupakan gua horisontal dengan panjang \pm 18 meter, lebar \pm 16 meter dan tinggi \pm 6 meter sampai 8 meter. Bagian dalam gua tidak ditemukan adanya lukisan dan permukaaannya banyak

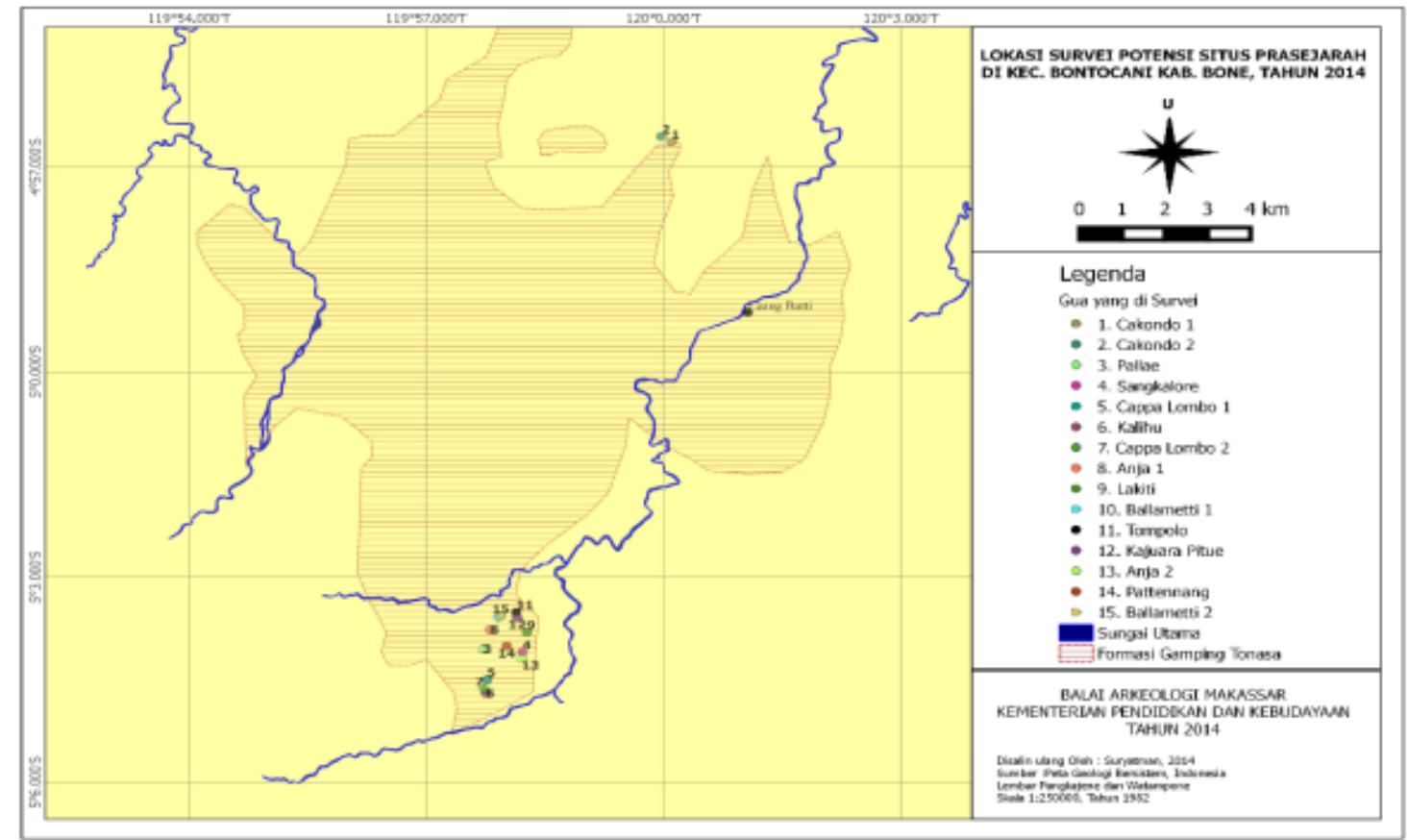

Gambar 3. Sebaran situs di Desa Langi dan Pattuku, Bontocani, Bone (Sumber: Dokumentasi Balar Sulsel, tahun 2014) 


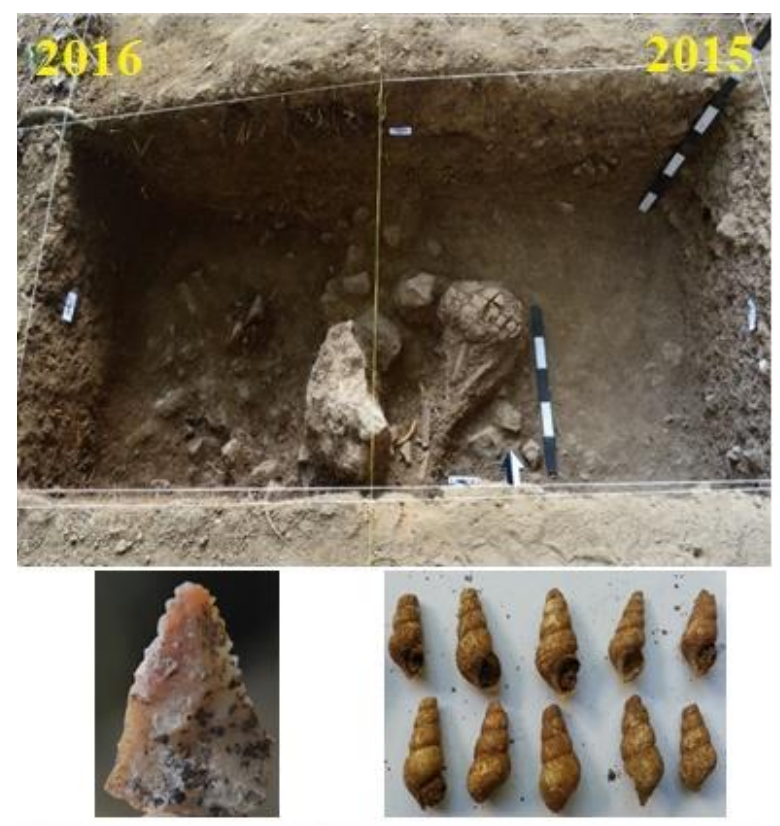

Gambar 4. Kotak Ekskavasi tahun 2015-2016 dan temuan rangka manusia, alat batu, dan kerang di Situs Bala Metti,Bone

(Sumber. Dokumentasi Balar Sulsel, Tahun 2016)

dijumpai bongkahan batu gamping yang berukuran besar serta lantai sedikit miring ke arah barat laut. Di antara bongkahan batu gamping tersebut ditemukan pecahan tembikar, kerang, tulang dan artefak batu. Sementara di bagian teras gua (bagian yang digali) temuan arkeologinya sangat padat, khususnya alat batu, kerang dan tulang.

Situs Bala Metti ditemukan tahun 2014 ketika tim Balai Arkeologi, Sulawesi Selatan yang dipimpin oleh penulis melakukan survei secara intensif di kawasan desa Pattuku, Bontocani. Dalam survei ini, telah ditemukan 12 situs gua dan ceruk. Sementara di kawasan Desa Langi, Bontocani juga ditemukan kurang lebih 10 gua dan ceruk. Masing-masing gua dan ceruk memiliki potensi arkeologi yang berbeda. Khusus Gua Bala Metti memiliki potensi arkeologi cukup tinggi dengan indikasi berupa temuan permukaan yang padat (alat batu, kerang, gerabah dan tulang). Karena potensi arkeologi yang begitu tinggi di situs Gua Bala Metti, maka sejak tahun
2015 hingga 2016 situs tersebut telah diekskavasi dengan membuka 4 kotak gali (Balar Sulsel, 2015 dan 2016).

Ekskavasi yang dilakukan di situs ini, khususnya kotak TP 1 (U1B1 dalam grid situs) sedalam $80 \mathrm{~cm}$ dari permukaan gua ( 8 spit) ditemukan dua lapisan budaya. Lapisan budaya 1 setebal $30 \mathrm{~cm}$, berupa matriks tanah lempung sedikit berpasir dengan tekstur agak kasar, agak keras dengan warna coklat kekuningan. Temuan arkeologi yang terendap dalam matriks ini, antara lain fragmen gerabah, kulit buah, arang, tulang, kerang, oker, tanah terbakar (burnt clay), dan artefak batu. Lapisan ini diduga sebagai lapisan budaya yang masih muda berkonteks dengan kehidupan manusia sekarang,

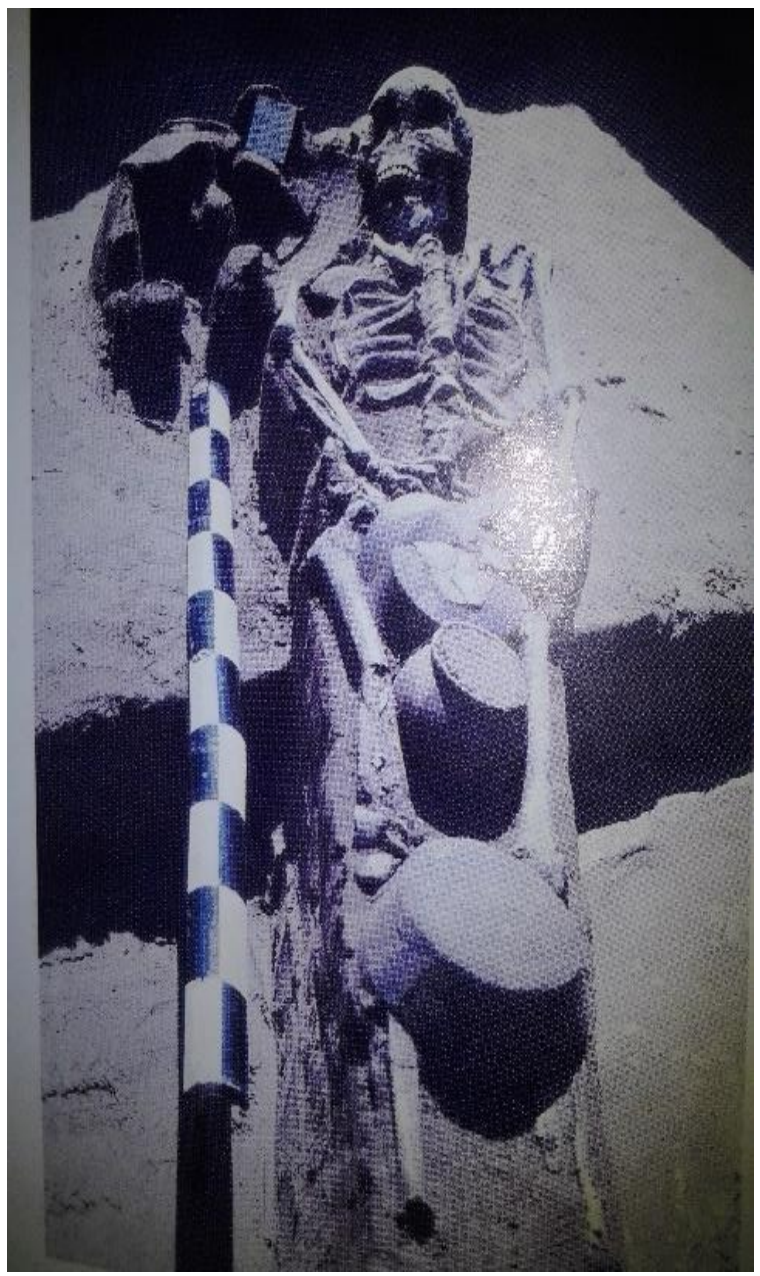

Gambar 5. Tradisi penguburan masa bercocok tanam di situs Plawangan, Jawa Tengah.

(Sumber: Dokumentasi Soegondho, Tahun 1995) 
setidaknya 1000 tahun yang lalu atau mungkin lebih muda lagi.

Alasannya, lapisan budaya ini berkonteks dengan fragmen gerabah baru (resen) dan selain itu, menurut informasi penduduk sekitar bahwa masa pendudukan Kompeni Belanda, banyak gua yang ditempati bersembunyi oleh penduduk sekitar. Jika melihat posisi keletakan fragmen gerabah resen ada pada bagian atas pada lapiasan $(10 \mathrm{~cm})$ dari permukaan situs, maka lapisan inilah yang kemungkinan berkonteks dengan kehidupan manusia sekarang (sangat baru).

Lapisan kedua (2) setebal $40 \mathrm{~cm}$ (dari spit 4 hingga spit 8) atau dari kedalaman 30 $\mathrm{cm}$ hingga $70 \mathrm{~cm}$ dari permukaan tanah situs. Matriks tanah lapisan ini adalah tanah lempung pasiran berwarna coklat gelap (kehitaman), dan sedikit kompak. Temuan arkeologi yang terendap dan berasoasiasi dalam lapisan ini, antara lain fragmen tulang binatang, kerang, oker, artefak litik dan rangka manusia. Khusus untuk temuan rangka manusia mulai ditemukan pada kedalaman $50 \mathrm{~cm}$ dari hingga kedalam 70 $\mathrm{cm}$ dari permukaan tanah gua. Asosiasi temuan arkeologi dengan rangka manusia, yaitu artefak batu, tulang binatang, kerang dan oker. Mengingat lapisan 2 ini tidak ditemukan adanya fragmen gerabah, maka untuk sementara diduga sebagai lapisan budaya yang lebih tua, mungkian lapisan akhir pleistosen atau awal holosen.

\section{Situs Leang Jarie}

Situs ini berada di Kelurahan Bantimurung, Kecamatan Bantimurung, Kabupaten Maros. Gua ini memiliki teras yang cukup lebar \pm 25 meter dan dihubungkan lorong dengan ruang yang agak besar. Orientasi gua ke arah selatan dengan pencahayaan yang cukup baik, kecuali pada ruangan utama yang dihubungkan dengan lorong sempit pencahayaannya sedikit kurang. Dalam ruangan tersebut terdapat beberapa lukisan cap tangan (hand stancil). Sementara pada dinding teras sebelah kiri juga terdapat banyak lukisan cap tangan dan satu buah lukisan manusia (terletak di dinding bagian tengah hampir sampai di atap gua). Lukisan cap tangan di gua ini telah didating oleh tim penelitian kerjasama antara Pusat Penelitian Arkeologi Nasional dan Wollogong University, Australia tahun 2012 dan 2013. Hasil dating yang diperoleh adalah 34.000 36.000 tahun yang lalu (Aubert et.al, 2014).

Pada permukaan gua ini banyak terdapat temuan arkeologi, seperti alat batu, tulang, kerang, dan tembikar. Di antara temuan arkeologi tersebut, alat batu merupakan temuan yang paling dominan dan hampir ditemukan disemua permukaan situs. Sisa manusia (rahang bawah yang masih ada sebagian gigi) di situs ini tersingkap pada bagian tengah situs. Temuan ini berasosiasi dengan artefak litik, kerang, tulang dan tembikar. Selain itu, temuan sisa manusia ini belum diketahui apakah terkubur dengan memakai wadah tembikar atau terkubur secara terlentang tanpa wadah. Sisa manusia di situs tersebut pertama kali ditemukan oleh penulis ketika melakukan kunjungan bersama peneliti dari Prancis tahun 2016.

\section{Gigi Manusia Situs Leang Jarie}

Gigi manusia di situs Leang Jarie ditemukan tersingkap pada permukaan gua yang berasosiasi dengan temuan arkeologi lainnya (alat batu, tembikar, tulang dan kerang). Temuan sisa manusia di situs ini berupa rahang bawah dan sebagian gigi. Khusus gigi sudah tidak memiliki puncak (occlusal), sebagian permukaan atas dari mahkota gigi (crown) sudah hilang (mature atau dewasa), sementara paracone, protocone, metacone dan hypocone yang runcing pada gigi sudah tidak ada, serta groove bagian lingual sudah berlubang, akar gigi tidak ada, lapisan luar gigi (enamel) retak dan masih menyatu, fissure bagian sisi gigi (buccal) masih tampak. Dari ciri-ciri yang ditampakkan dari temuan gigi situs Leang Jarie ini adalah rahang bawah gigi geraham kanan bagian tengah (molar 2) dari 


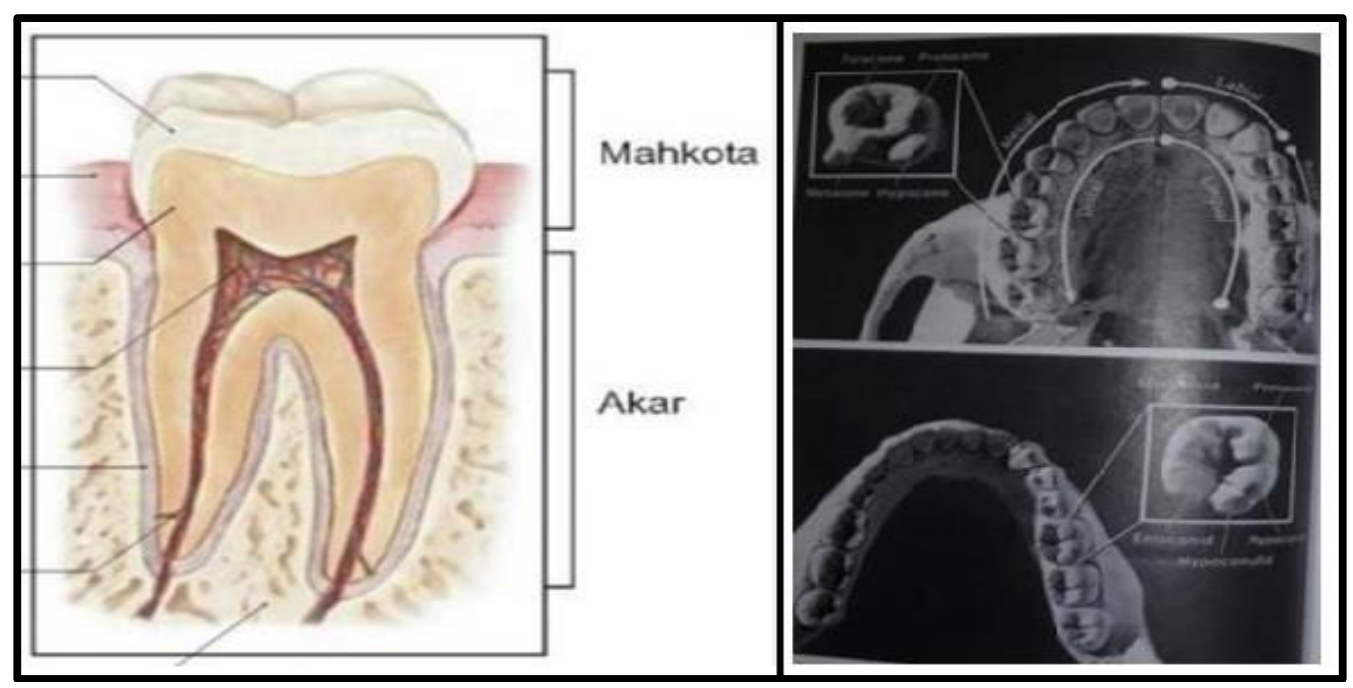

Gambar 6 dan 7. Bagian dan istilah pada gigi manusia.

(Sumber. Gambar 6. softimu.com, 2015.

Gambar 7. White, T. D. dan Pieter A. F., 2005).
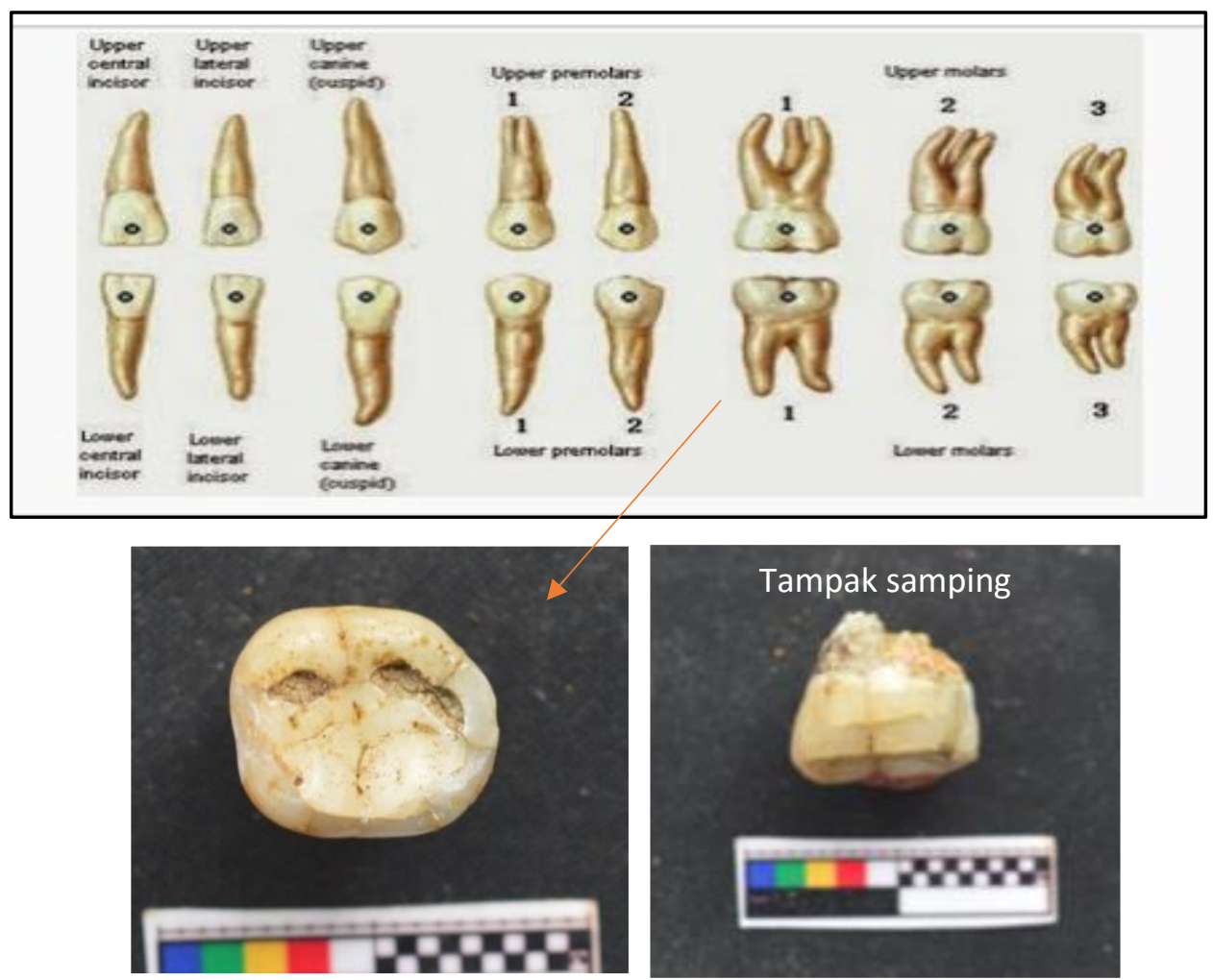

Gambar 8. Jenis-jenis gigi manusia.

(Sumber. www. softimu.com, 2015)

Gambar 9. Temuan gigi manusia di situs Leang Jarie, Maros.

(Sumber. Dokumentasi Budianto Hakim, Tahun 2016)

gigi manusia yang sudah dewasa di atas 20 tahun. Lebar permukaan gigi dan panjang gigi $\pm 1.1 \mathrm{~cm}$.

Gigi geraham yang ditemukan dalam penggalian merupakan gigi geraham bawah urutan 2 dalam susunan gigi manusia (gambar 9). Gigi ini berfungsi menggiling, menggilas, melumat, menghancurkan, mengunyah dan menghaluskan makanan. Gigi geraham bawah biasanya memiliki 2 
akar, sementara gigi geraham bagian atas memiliki 3 akar. Jika melihat keausan permukaan gigi gerahan tersebut, sangat jelas kalau geraham ini dipakai dalam waktu yang cukup lama. Keasun akibat fungsinya dicirikan oleh hypocone gigi sudah tidak ada dan juga memliki kerusakan berupa lubang.

\section{Gigi Manusia Situs Bala Metti}

Sisa manusia (gigi dan tulang lainnya) dalam penggalian ditemukan pada kedalaman $60-80 \mathrm{~cm}$ dari permukaan lantai gua atau merupakan lapisan budaya yang mengandung artefak litik (serpih, bilah, mikrolit, mata panah bergerigi dan palu batu), fragmen tulang binatang (kuskus, monyet, tikus, kelelawar, babi, ular, katak, anoa, burung dan ikan), fragmen kerang (brotia, salinator burnama, veneridae), dan beberapa temuan tanah terbakar (burn clay) dan oker (Balar Sul-Sel, 2015).

Temuan gigi manusia untuk sementara yang berhasil ditampakkan terdiri dari tengkorak (cranium), rahang (mandible dan maxila), tulang kaki (tibia), tulang lengan (humerus) dan beberapa gigi. Jika melihat posisi keletakan tulang panjang dan tengkorak, tampaknya sisa manusia di situs tersebut dikubur secara langsung tanpa memakai wadah dengan posisi membujur Utara-Selatan. Sekeliling rangka banyak ditemukan batu gamping yang mungkin sengaja dipasang secara melingkar sebagai penguat. Secara keseluruhan kondisi rangka, yaitu rapuh dan mudah pecah. Bahkan tengkorak kepalanya pecah dan terhambur (gambar 10).

\section{Interpretasi Awal Temuan Penelitian}

Keletakan temuan sisa-sisa manusia dalam penggalian Balar Sulawesi Selatan tahun 2015 di situs Gua Bala Metti, Bontocani, Bone, yaitu berada pada lapisan budaya yang berkonteks atau bercampur dengan alat batu (mata panah bergerigi atau lancipan Maros, mikrolit, dan serpih-bilah), fragmen tulang dan kerang. Jika berdasarkan hasil penggalian tersebut bahwa alat batu jenis lancipan Maros dan mikrolit merupakan dua tipe alat batu yang menjadi ciri khas budaya Toala. Maka temuan sisasisa manusia di Gua Bala Metti untuk sementara dapat dikatakan sebagai manusia pendukung Budaya batu di Bone yang berlangsung antara $8000-3000 \mathrm{BP}$. Hal ini, sesuai hasil pertanggalan yang dilakukan oleh Glover di situs Ulu Leang, Maros

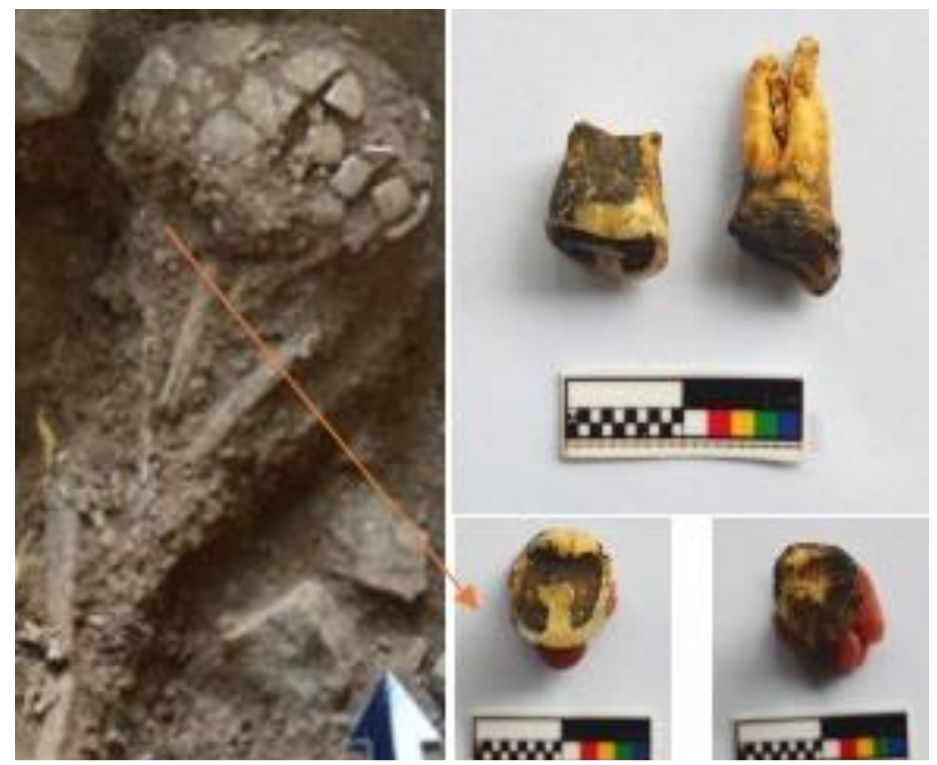

Gambar 10. Temuan sisa manusia (tengkorak, rahang, tulang paha, tulang lengan dan gigi.

(Sumber: Dokumentasi Budianto Hakim, Tahun 2016 ) 
(Glover, 1978: 87; Bulbeck et.al, 2000:15). Jika demikian, maka manusia pendukung budaya batu di daerah Bontocani, Bone dapat disejajarkan dengan ras Austromelanesid.

Sementara, hasil penggalian lanjutan Balai Arkeologi Sulawesi Selatan tahun 2016 di situs Gua Balametti, Bontocani, Bone diperoleh informasi yang berbeda. Kotak yang digali di sebelah barat kotak penemuan sisa manusia digali tahun 2015 (lihat foto situs di atas), pada lapisan budaya yang sama dengan temuan sisa-sisa manusia, juga ditemukan fragmen tembikar berasosiasi dengan artefak batu (lancipan Maros, serpih-bilah dan mikrolit), fragmen tulang dan fragmen kerang. Kalau asosiasi temuan pada kotak penggalian tahun 2016 ini dijadikan acuan, maka dapat dikatakan bahwa sisa-sisa manusia tersebut adalah ras Mongloid Selatan. Penjelasan ini diperkuat oleh adanya temuan tembikar pada lapisan budaya yang sama dengan lapisan budaya dimana sisa-sisa manusia ditemukan. Teknologi tembikar adalah salah satu budaya yang dibawa oleh penutur Austronesia (ras Mongoloid Selatan) masuk ke Nusantara sekitar 4000 tahun yang lalu (Bellwood, 2000).

Analisa selanjutnya berdasarkan penjelasan di atas bahwa temuan artefak batu, khususnya alat serpi-bilah, lancipan Maros dan mikrolit, kemungkinan juga telah diadopsi dengan baik oleh manusia masa bercocok tanam (ras Mongoloid Selatan). Artinya manusia pendukung masa bercocok tanam pernah hidup berdampingan dengan manusia pendukung masa berburu tingkat lanjut (Austromelanesid). Atau kemungkinan lancipan Maros dan mikrolit memang hasil budaya asli dari masa bercocok tanam. Untuk menjawab hal itu, tentu masih dibutuhkan kajian dan analisis secara mendalam pada penelitian akan datang.

Adapun temuan sisa-sisa manusia di situs Leang Jarie, Maros untuk sementara dapat disejajarkan dengan sisa manusia yang pernah ditemukan di Sulawesi Selatan sebelumnya, yaitu manusia pendukung budaya bercocok tanam. Pendapat ini, diperkuat oleh posisi temuan yang tersingkap secara in-situ pada permukaan situs. Temuan sisa-sisa manusia tersebut berasosiasi dengan beberapa temuan arkeologi, seperti tembikar, alat batu, tulang dan kerang. Dan memang pada penelitian terdahulu, beberapa gua prasejarah yang pernah digali di wilayah Maros telah ditemukan sisa-sisa manusia dari pendukung budaya bercocok tanam (ras Mongoloid Selatan), seperti temuan sisa manusia di Gua Karrasa, Pattunuang Asue, Maros dan Gua Pettakere, Leang-Leang, Maros.

\section{PENUTUP}

Sisa manusia ditemukan di situs Bala Metti, Bontocani, Bone dan situs Leang Jarie, Maros. Jika berdasarkan keletakan dan konteks arkeologinya, diperkirakan bahwa sisa-sisa manusia pada kedua situs tersebut adalah sisa manusia dari masa bercocok tanam (ras Mongoloid Selatan). Sementara berdasarkan ciri dan keausan gigi, diduga usia manusia pendukung pada kedua situs ini adalah dewasa (mature). kedewasaan dari temuan gigi, dicirikan oleh atap gigi yang sudah hilang, mahkota gigi sudah hilang, groove bagian lingual gigi sudah berlubang, dan email gigi sudah retak.

Kalau benar sisa-sisa manusia yang ditemukan di situs Bala Metti dan Leang Jarie adalah sisa manusia dari ras Mongoloid Selatan, maka dapat dikatakan bahwa pada masa bercocok tanam manusia pendukungnya juga masih melanjutkan pembuatan alat batu jenis serpih yang begitu maju, yaitu dengan membuat lancipan Maros (mata panah bergerigi) dan mikrolit. Dengan demikian, pendapat oleh para peneliti terdahulu yang menganggap bahwa lancipan Maros dan mikrolit adalah produksi dari manusia pada masa berburu tingkat lanjut, untuk sementara pendapat itu sudah tidak relevan dalam konteks sekarang. Untuk memperkuat argumen tersebut, 
dibutuhkan informasi umur dari hasil pertanggalan (dating) dan analisis lainnya. Analisis yang dimaksud, anatara lain; C14, analisis DNA maupun Uranium Series. Untuk analisis C14 dapat diperoleh dari sisa pembakaran (arang) yang berkonteks dengan temuan gigi manusia, sementara analisis DNA dapat dilakukan dari sisa akar gigi manusia yang tersisa pada kedua situs serta analisis uranium series dapat dilakukan dari semuan jenis temuan yang berasosiasi dalam satu layer budaya.

\section{DAFTAR PUSTAKA}

Aubert, Maxim, Adam Brumm, M. Ramli, T. Sutikna, E.W. Saptomo, Budianto Hakim, M.J. Morwood, G.D. van den Berg, L. Kinsley \& A. Dasetto. 2014. Pleistocene cave art from Sulawesi, Indonesia. Nature. Doi: 10.1038/nature13422. Vol. 514. Macmilan Publishers Limited. All rights reserved

Balar Sulsel, 2014. Laporan Penelitian Arkeologi Prasejarah di Kawasan Bontocani, Bone. Sulawesi Selatan. Balai Arkeologi Sulawesi Selatan (tidak terbit).

2015. Laporan Penelitian Arkeologi Prasejarah di Kawasan Bontocani, Bone, Sulawesi Selatan. Balai Arkeologi Sulawesi Selatan (tidak terbit).

2016. Laporan Penelian Arkeologi Prasejarah di Kawasan Bontocani, Bone, Sulawesi Selatan. Balai Arkeologi Sulawesi Selatan (tidak terbit).

Bellwood, Peter, 2000. Prasejarah Kepulauan Indo-Malaysia. (Edisi Revisi). Penerbit PT. Gramedia Pustaka Utama. Jakarta

Bulbeck, David; Monique Pasqua and Adrian de Lello. 2000. "Culture History of the Toalean of South Sulawesi, Indonesia”. Asian Perspectives, Vol. 39, No.1-2, 2000.

Duli, Akin dan M. Nur, 2016. Prasejarah Sulawesi. Makassar: Fakultas Ilmu Budaya, Universitas Hasanuddin.

1978. "Survey and Excavation in The Maros District, South Sulawesi, Indonesia: The 1975 Field Saeson". Bulletin of the Indo-Pacific Prehistory Association. 1:113154.

Poesponegoro M. D., 1984. Sejarah Nasional Indonesia I. Jakarta: Balai Pustaka, Kementerian Pendidikan dan Kebudayaan.

Soegondho, Santoso, 1995. Tradisi Gerabah Di Indonesia: Dari Masa Prasejarah hingga Masa Kini. Jakarta: Himpunan Keramik Indonesia

White, Tim. D and Pieter A. Folkens. 2005. The Human Bones Manual, London: Elsevier Academi Press. 
Zaim, Yahdi; Tanudirjo, Daud Aris; Widianto, Harry; Prasetyo, Bagyo, 2012. Manusia Dan Budaya Setelah Zaman Es Terakhir. Dalam Buku. Indonesia Dalam Arus Sejarah (Ed. Umum. Taufik Abdullah). Jakarta: Ichtiar Baru van Hoeve, kerjasama Kemendikbud.

Sumber Internet:

http://www.softimu.com. 2015. Pengertian Fungsi, dan Struktur Gigi Manusia. 
Lampiran Peta Lokasi Situs Bala metti di Kabupaten Bone, Sulawesi Selatan

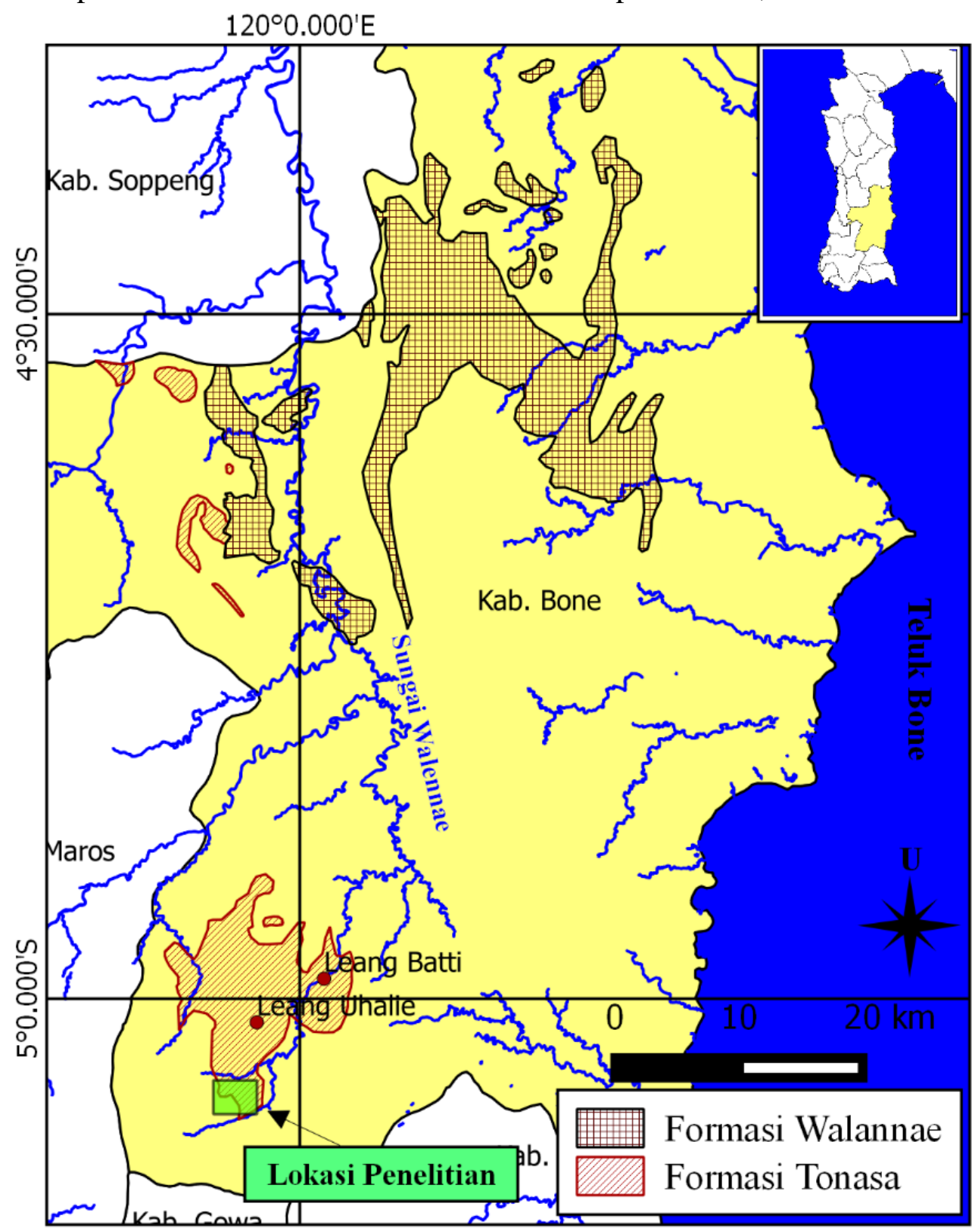

